\title{
Analysis of Cross Border Trade between Regency of North Central Timor and Enclave District of Oekusi (Timor Leste)
}

\author{
Kamilaus Konstanse $\mathrm{Oki}^{1}$, I Nyoman Djinar Setiawina ${ }^{2}$ I.G.W. Murjana Yasa ${ }^{3}$, \\ Made Heny Urmila Dewi ${ }^{4}$ \\ ${ }^{\text {I}}$ (Doctorate Program of Economics Science, Udayana University, Bali, Indonesia) \\ 2, 3,4 (Business and Business Faculty, Udayana University, Bali, Indonesia)
}

\begin{abstract}
Cross border trade is a trading activity performed by community residing in border area of neighboring countries. The regency of North Central Timor is a region with direct land border with Timor Leste particularly enclave district of Oekusi. Post Timor Leste's independence, cross border trade is unavoidable. This research was conducted in border area of North Central Timor Regency particularly in 6 (six) districts which bordered with enclave district of Oekusi. Data analysis being used was Structural Equation ModelingPartial Least Square (SEM-PLS). From the result of data analysis, it was found that social capital has positive effect directly towards entrepreneurship and cross border trade, institutional changes has positive and significant effect directly towards entrepreneurship, and has positive and insignificant effect towards cross border trade, entrepreneurship has positive and significant effect directly towards prosperity. Social capital has positive and significant effect indirectly towards cross border trade through entrepreneurship and has positive and significant effect towards prosperity through cross border trade. Institutional changes has positive and significant effect indirectly towards cross border trade through entrepreneurship and has positive and significant effect toward prosperity through cross border trade, entrepreneurship has positive and significant effect indirectly towards prosperity through cross border trade.
\end{abstract}

Keywords: Social Capital, Institutional Changes, Entrepreneurship, Cross Border Trade, Prosperity

\section{Introduction}

Trading is an important activity for improvement of economic growth and people's welfare and as a source of foreign exchange to finance the growth. Therefore trading is an important factor in economic activity of a region. According to Bustami (2012), trading activity of a country becomes indication for prosperity level of people and as a benchmark of economic level of that country.

Cross border trade is a trading activity carried out by people residing in the border area of neighborhood country to get extra income. Mechanism of cross border trade management in general is still traditional in nature and involving local population. It is to be said traditional because the approaching pattern is still relatively traditional, although interaction process is carried out between communities of different countries.

According to the Law No.43 year 2008 regarding the territory of the region, border area is an integral part of state's territory located along the border of Indonesia's territory with neighboring country. Border area is a main manifestation of territorial sovereignty or region where border area has an important role in determining the border of sovereignty and utilizing resources.

Post Timor Leste's independence as a new country, the Province of East Nusa Tenggara is automatically becoming a border province. The condition resulted in the Province of East Nusa Tenggara becomes strategic since it is located in the frontline of Indonesia in the border area and as a barometer of the picture of national development. The regency of North Central Timor is one of regency's territories directly with land border with Timor Leste in particular with enclave district of Oekusi. The border of regency of North Central Timor with enclave district of Oekusi extending along for $115 \mathrm{~km}$ (one hundred and fifteen kilometers) and covering 6 (six) districts and 40 (forty) villages.

Border territory of the Regency of North Central Timor and enclave district of Oekusi becomes the choice of research due to people's characteristic and location of region of Oekusi district which is unique and interesting. People from both countries have close kinship but separated by political interest in different government's territory. It is called unique and specific because geographically, territory of Oekusi district is an enclave territory since it is located in the territorial of Indonesia region.

Social capital is a basic power owned by a society in building a relationship both in economy and sociocultural. Cross border trade gives contribution to trader's welfare by harnessing kinship relation which creating trust, establishing relation or network and norm strength rooted in cultural similarity. According to Coleman (1986), people conducting economic transaction repeatedly in long term due to the strength of social capital (trust, network, and norm). 
The shifting of behavior, interactive pattern supported by regulation by government gives room for creation of the order changing and community tradition which has long been established. The high level of people's demand in Oekusi district around the border resulted in the shifting of behavior pattern of local people. The choice for business by choosing to be a trader who was previously as a farmer is very high. Associated of transformation is regulation factor by government which gives room and facilitation due to facilities available for crossing people and goods without cost and uncomplicated mechanism. Regulation which is keenly felt is the availability of Cross Border Pass document for people crossing and Goods Cross Border Pass for goods crossing. According to Manig (1991), the institutional changing is encouraging for the occurrence of social engineering by changing the structure of economic, social and culture of society, meanwhile according to Hira and Hira (2000), institutional changing occurred due to reaction of new economic factor.

Factor of proximity of settlement resulted in people mutually understand on the character and needs of each other. The relationship leads to business relation to fulfill the needs of all parties is running well. Traders in border area have self confidence on such business continuity since well established communication through strong kinship. According to Ireland et al (2003), entrepreneurship factor was affected by people in right location, had knowledge on the nature and character of local people, had established relationship or business connection, had sufficient knowledge on people needs or market needs.

Subjective outlook that border area is a business oriented new economic opportunities, provides positive value on traders' economic condition. Profession switching as conventional farmers, as contract employees, to become businessmen by harnessing border community as a market and source of income, has given positive effect on the economic life of the family. The shifting of behavior is not limited to economic sector but spreading to creation oriented behavior and new innovation with economic value.

The strength keeps on to be encouraged through integrated policy, thoroughly with renewal spirit and changing in every aspects and its dimensions, through the changing in thinking paradigm, behavior, interaction pattern followed by good regulation from government. All of it is encouraged to harness the opportunity and potential of natural resources in border area, both in economy and sociocultural, by gradually improving the welfare of traders in border area.

\section{Literature Review}

International trade is a trade performed by a country with another country on basis of mutual agreement. The said trade is relationship between individual and individual, between individual and a government of one country, or government of one country with government from another country in the activity of sales and purchasing of goods and services. International trade has positive effect towards economic growth of any country. Rahardja (2002), had argued that driving force for development was international trade.

According to Case (1996), the paradigm which believed that economic condition of one country would be more prosperous if able to maximize the trade. The consequence was to maximize export and minimize import. A country would benefit from international trade if performing product specialization and exporting goods in which that country could produce more superior relatively and importing goods in which that country produced relatively less or not productive.

Bustami (2012), argued that globalization had tore down barrier wall between countries and replacing it with free trade cross border. The increasing flow of trade both within the island and between islands besides the positive effect toward improving the welfare of traders, was also by increasing local revenue through tax revenue and retribution. Phenomenon which had developed so far especially in border area was the number of commodities being traded informally. Informal trade flow in border area had some challenges and problems complex enough which differs from non border regional trade, so that the involvement of government and various elements is urgently needed to formulate the trade policy specific in border area.

Inkong et al (2013), conducted a research about the Role of Cross Border Trade in Accelerating Infrastructure Development in the District of Kayan Hulu Regency of Malinau, revealed that the process of the existence of cross border trade in border area between district of Kayan Hulu Regency of Malinau and neighboring country Malaysia Serawak in general due to geographical factor and its topography, cost and price factors, and cultural background. Those factors led to local people around border area tended to perform informal transaction to meet the needs for nine staples and other goods without through legal process as regulated in trade procedure between countries.

Cross border trade although is a negative trade practice for government income in general, but provides a positive impact for individual, their family or kinship who have participated in the trade. Cross border trade has contributed towards food security, creation of employment, providing an income and poverty alleviation, complementing formal commercial network and contributing to new market opening in the region around community settlement. 


\subsection{Strategy for Developing the Economy in Border Region}

The changing of border paradigm from security concept towards prosperity concept has an impact on the side of economic growth in border area. Interaction which occurred leads to the development of activities and economic activities of the people in the border region. The next section explains about concepts in economic growth and indicators related to economic growth.

Economic perspective of border area theoretically that economic growth has an impact on integration effect of economy followed by spatial change or land usage. This condition occurred with terms such as appropriate climate between economic model, spatial impact, and economic policy which support it. The model of traditional location and new model of economic geography indicates that external trade can change spatial pattern of land usage in border area (Niebuhr \& Stiller, 2001).

The development of economic activities in border area cannot be separated from market potential owned by it. By observing location model and consideration of marketing area in border region viewed as a disadvantaged area for the growth of market potential. The consideration is based on several obstacles which often occurred (tariff, policy, and other obstacles) in border area which resulted in the potential for economic growth is not optimal due to marketing coverage area.

According to Branch (1998), there were several factors which affecting the growth of border area such as physical form (land utilization and space structure), function of area (economic, trade and industry function) influenced by people activities, the nature of society (culture and beliefs, social and life style), availability of general elements (road network, clean water, etc.). Those factors had an important role in the development of border area. The growth of economic activities could be characterized by transformation on spatial aspect, social and growing infra-structure.

Basri (2011), argued that problems faced by border area in local level were in the form of isolation, underdevelopment, poverty, expensiveness of goods and service prices, limitation of facilities and infrastructure of public service, low quality of human resources in general, and uneven population distribution. In this moment, government as the controller party must be in the frontline to seek the best solution with approach and program favoring to the improvement of public's welfare.

According to Krisman Manurung (2011), development strategy of border area focused on economic growth especially in centers of potential border area through the basis of populist economics with the availability of appropriate infrastructure, creating conducive and constructive political stability in order to support the implementation of economic growth in border area, to put community empowerment as a main approach by increasing the role and public participation in border area for real.

\subsection{Public Welfare}

Social welfare with social justice as written in the Constitution of 1945, Article 27 paragraph 2, mandating that every citizen is entitled for job and appropriate living for humanity. To overcome unemployment is a main priority in development so that public's socioeconomic welfare can be materialized.

According to Todaro (2012), the welfare of a person's life in reality, had many success indicators which could be measured. Welfare indicator of one region was measured through the level of poverty, number of illiterate people, number of literate people, damage to nature and environment, water pollution and the level of Gross Domestic Product. The welfare of one region was determined from the availability of resources including human resources, physical resources and other resources. Those three resources interacted in development process to achieve economic growth and improved public's welfare.

Deaton (2003), in conducting research regarding Health, Inequality, and Economic Development, stated that income distribution was authorization owned by government and affecting the level of public welfare. Inequality of income distribution would create disparity, the result was part of society could not reach the basic needs. Public's welfare was measured by level of income, fulfillment of basic needs such as food and health service.

Coordinator Ministry of Public Welfare provides the meaning of welfare as a condition of people who has been fulfilled of their basic needs. The basic needs consist of adequacy and quality of foods, clothing, housing, health, education, employment, and other basic needs (www.menkokesra.go.id).

In the National Development Planning for Medium Term 2004-2009, it was described that to facilitate regional government in order to maintain territorial integrity, to achieve welfare in border area required a concrete approach which favoring public's economic needs. The steps which should be prepared to create public's welfare in border area by improving the development of social and economic facilities and infrastructure, increasing government's alignment in financing for development especially for developing economic facilities and infrastructure in border area, participation and increasing cooperation from society. 


\section{Framework Of Research Concept}

Cross border trade is carried out by people of two adjoining countries in population settlement and mutually in need for fulfillment of economic needs. Government's interference to intervene market in cross border trade is very small and only limited in process control role so that it provides comfort, safety and politics in the border. The illustration of framework of research concept can be seen in Figure 1.

Figure 1. Framework of Research Concept

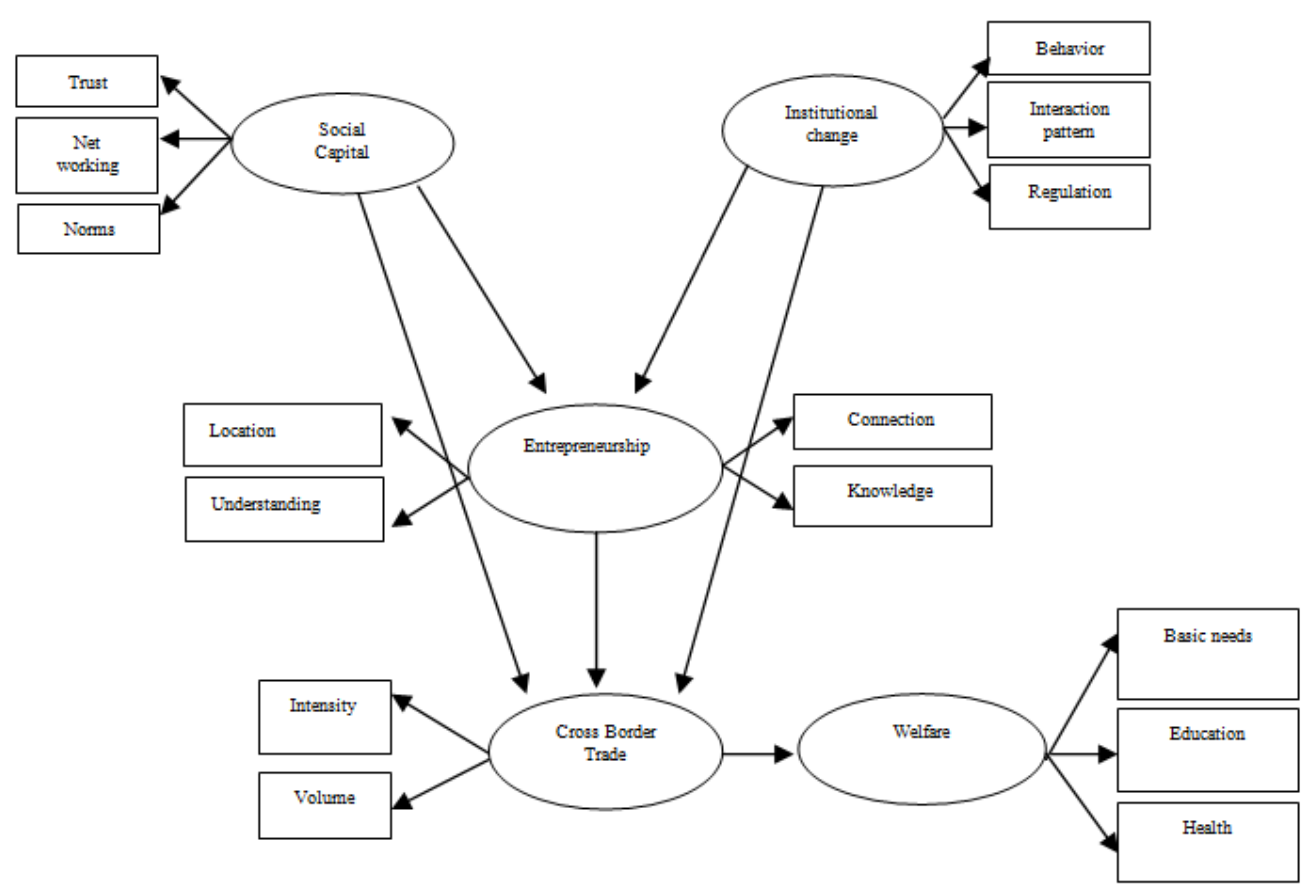

\subsection{Latent Variables and Indicators}

This research has 5 (five) latent variables/constructs, namely social capital, institutional change, entrepreneurship, cross border trade, and welfare. Latent variable indicator from social capital (X1) is trust (X11), networking (X12), norms (X13). Variable indicator of institutional change (X2) is depicted as, behavior (X21), interaction pattern (X22), regulation (X23). Variable indicator of entrepreneurship (Y1) is reflected by location (Y11), understanding (Y12), connection (Y13), knowledge (Y14). Variable indicator of cross border trade (Y2) can be described by intensity (Y21), volume (Y22), meanwhile variable indicator of welfare (Y3) is basic needs (Y31), education (Y32) health (Y33).

\subsection{Research Hypothesis}

Hypothesis in this research are:

1) Hypothesis (H1), Social capital has positive and significant effect towards entrepreneurship, cross border trade, between the Regency of North Central Timor and Enclave District of Oekusi.

2) Hypothesis (H2), Institutional Change has positive and significant effect towards entrepreneurship, cross border trade, between the Regency of North Central Timor and Enclave District of Oekusi.

3) Hypothesis (H3), Entrepreneurship has positive and significant effect towards cross border trade in border area between the Regency of North Central Timor and Enclave District of Oekusi.

4) Hypothesis (H4), Cross border trade has positive and significant effect towards traders' welfare in border area between the Regency of North Central Timor and Enclave District of Oekusi.

5) Hypothesis (H5), Social capital has significant effect indirectly towards cross border trade through entrepreneurship, and towards prosperity through cross border trade in border area between the Regency of North Central Timor and Enclave District of Oekusi.

6) Hypothesis (H6), Institutional change has significant effect indirectly towards cross border trade through entrepreneurship, and towards traders' welfare through cross border trade in border area between the Regency of North Central Timor and Enclave District of Oekusi.

7) Hypothesis (H7), Entrepreneurship has significant effect indirectly towards traders' welfare through cross border trade in border area between the Regency of North Central Timor and Enclave District of Oekusi. 


\section{Method Of Research}

The method of research is conducted with stages as follows; formulation of problems, establishing hypothesis of research, identifying variables of research, determining population and samples of research, data collection by constructing questions in questionnaire, tabulating and analyzing research data, testing established hypothesis, conducting discussion and interpretation, drawing a conclusion and providing suggestions.

\subsection{Research Location}

The research was conducted in the Regency of North Central Timor, Province of East Nusa Tenggara, on 4 (four) districts directly bordering with enclave district of Oekusi. Districts which had been a location of research were a main entrance and had a border market which legally operated. Those four districts were district of North Insana, district of North Bikomi, district of Bikomi Nilulat, and district of Mutis.

\subsection{Method of Data Collection and Data Analysis}

Method of research being used in this study was providing questionnaire, namely data collection by giving a number of written questions structurally to the respondents of research related to variables being studied in this research.

Data analysis being used in this research was by using quantitative data method of Structural Equation Modeling-Partial Least Square (SEM-PLS). According to Abdillah and Hartono (2015), the method of SEMPLS was a powerful method since it did not assume a data measurement scale and also had been used to confirm a theory.

\section{Result Of Research And Discussion}

Processing of research's outcome by using program of SEM-PLS 3.0, with number of variables being analyzed are five variables and fifteen indicators.

\subsection{Testing of outer model}

Concept and model was meant to predict relational ties and testing construct validity and instrument reliability (Abdillah and Hartono, 2015). Procedure for outer model test was measured through bootstrapping approach.

\subsubsection{Testing of convergent validity}

Convergent validity shows a correlation between reflexive indicator score with its latent variable score. Convergent validity can be seen through outer loading value between indicator variable and its construct. Outer loading value $>0.7$, then it can be said that indicator and its latent variable has high correlation, but if the value of outer loading is 0.5 up to 0.6, it is still considered sufficient (Chin, 2003). According to Abdillah and Hartono (2015), that is the higher the value of loading factor, then the more important the role of loading in interpreting matrix factor. The value of outer loading in this research is shown in Table 1.

Table 1. Outer Loading Indicator Against Construct

\begin{tabular}{|l|l|l|l|l|l|}
\hline & X1 & X2 & Y1 & Y2 & Y3 \\
\hline X11 (Trust) & 0.502 & & & & \\
\hline X12 (Net Working) & 0.651 & & & & \\
\hline X13 (Norms) & 0.915 & & & & \\
\hline X21 (Behavior) & & 0.934 & & & \\
\hline X22 (Patterns of interaction) & & 0.970 & & & \\
\hline X23 (Regulation) & & 0.904 & & & \\
\hline Y11 (Location) & & & 0.957 & & \\
\hline Y12 (Understanding) & & & 0.948 & & \\
\hline Y13 (Connection) & & & 0.946 & & \\
\hline Y14 (Knowledge) & & & 0.928 & & \\
\hline Y21 (Intensity) & & & & & 0.954 \\
\hline Y22 (Volume) & & & & 0.632 & \\
\hline Y31 (Basic needs) & & & & & \\
\hline Y32 (Education) & & & & & 0.921 \\
\hline Y33 (Health) & & & & & 0.944 \\
\hline
\end{tabular}

Source : Output data analysis by SEM-PLS

In table 1 is shown that the average of indicators from all constructs have the value of outer loading > 0.7 except social capital variable (X1), on trust and norms indicator and housing needs indicator on welfare variable (Y3) which has outer loading $<0.7$. Even though the value of outer loading $<0.7$, but correlation is considered sufficient since it still qualified. As suggested by Abdillah and Hartono (2015), that if loading score is between $0.5-0.7$, it is better not to erase or delete the indicator if AVE score > 0.5. According to Chin 
(2003), correlation between reflexive indicator score and its latent variable score, the value of outer loading 0.5 - 0.6 is considered sufficient on the number of indicators per construct which not great in which ranging between 3 to 7 indicators.

\subsubsection{Testing the Discriminant Validity}

The value of Discriminant Validity can be tested by looking at the value of cross loading. Discriminant validity is measured through cross loading value and Average Variance Extracted (AVE). Criteria for AVE value must be $>0.5$, and cross loading value between indicator and its construct must be greater than correlation value between indicator and its construct. Cross loading value and Average Variance Extracted (AVE) can be seen in Table 2 and Table 3.

Table 2. The Value of Latent Variable AVE and Reflexive Indicator

\begin{tabular}{|l|l|}
\hline & AVE \\
\hline Social Capital(X1) & 0.504 \\
\hline Institutional Changes(X2) & 0.877 \\
\hline Entrepreneurship (Y1) & 0.893 \\
\hline Cross Border Trade(Y2) & 0.655 \\
\hline Welfare (Y3) & 0.674 \\
\hline
\end{tabular}

Source : Output data analysis by SEM-PLS

Table 3. Cross Loading Value Indicator Against Construct

\begin{tabular}{|l|l|l|l|l|l|}
\hline & X1 & X2 & Y1 & Y2 & Y3 \\
\hline X11 (Trust) & 0,502 & 0,756 & 0,708 & 0,613 & 0,811 \\
\hline X12 (Net Working) & 0,651 & 0,838 & 0,747 & 0,804 & 0,725 \\
\hline X13 (Norms) & 0,915 & 0,921 & 0,898 & 0,858 & 0,909 \\
\hline X21 (Behavior) & 0,902 & 0,934 & 0,897 & 0,878 & 0,911 \\
\hline X22 (Understanding) & 0,790 & 0,970 & 0,915 & 0,854 & 0,935 \\
\hline X23 (Regulation) & 0,659 & 0,904 & 0,780 & 0,676 & 0,767 \\
\hline Y11 (Location) & 0,770 & 0,913 & 0,957 & 0,840 & 0,899 \\
\hline Y12 (Understanding) & 0,758 & 0,893 & 0,948 & 0,835 & 0,922 \\
\hline Y13 (Connection) & 0,835 & 0,865 & 0,946 & 0,866 & 0,902 \\
\hline Y14 (Knowledge) & 0,823 & 0,832 & 0,928 & 0,841 & 0,869 \\
\hline Y21 (Intesity) & 0,853 & 0,915 & 0,945 & 0,954 & 0,944 \\
\hline Y22 (Volume) & 0,777 & 0,812 & 0,830 & 0,632 & 0,782 \\
\hline Y31 (Basic needs) & 0,773 & 0,902 & 0,907 & 0,770 & 0,921 \\
\hline Y32 (Education) & 0,853 & 0,915 & 0,945 & 0,954 & 0,944 \\
\hline Y33 (Health) & 0,615 & 0,736 & 0,825 & 0,790 & 0,531 \\
\hline
\end{tabular}

Source : Output data analysis by SEM-PLS

Appropriateness of construct being made can be seen from discriminant validity through the value of Average Variance Extracted (AVE) which in general being used in reflexive indicator, aims to measure internal consistency of a construct. Social capital construct, institutional change, entrepreneurship, cross border trade and traders' welfare have AVE value above 0.50 so that considered good.

\subsection{Testing of Structural Model (inner model)}

Structural model evaluation (inner model) is a testing between latent variable (construct) to find out relationship between constructs by looking at the value of $\mathrm{R}^{2}$ and $\mathrm{Q}^{2}$. Based on the value of $\mathrm{R}^{2}$, relationship between variables is classified as "strong" if $\mathrm{R}^{2}$ value $>0.7$, it is classified as "substantial" if $\mathrm{R}^{2}$ value equals to 0.67 , it is classified as "moderate" if $\mathrm{R}^{2}$ equals to 0.33 , and it is classified as "weak" if $\mathrm{R}^{2}$ value equals to 0.19 (Abdillah and Hartono, 2015). The value of R-square $\left(\mathrm{R}^{2}\right)$ as the result of SEM-PLS test in this research can be seen in Table 4.

Table 4. The Value of R-square for Construct

\begin{tabular}{|l|l|l|}
\hline & R Square & Information \\
\hline Entrepreneurship (Y1) & 0.872 & Strong \\
\hline Cross border trade(Y2) & 0.825 & Strong \\
\hline Welfare (Y3) & 0.830 & Strong \\
\hline
\end{tabular}

Source : Output data analysis by SEM-PLS

In the Table 4 it shows that the value of $\mathrm{R}^{2}$ for construct of entrepreneurship, cross border trade, and traders' welfare all located above or $>0.7$, it means that all

the constructs in the model can be considered good. The value of $\mathrm{R}^{2}$ of entrepreneurship construct (Y1) is equal to 0.872 . Thus it shows that entrepreneurship construct in inner model can be considered strong, and 
entrepreneurship construct can be explained by social capital construct and institutional change construct equals to 87.2 percent, meanwhile the rest of 12.8 percent can be explained with other variables. Meanwhile the value of $\mathrm{R}^{2}$ of cross border trade construct of 0.825 is greater than 0.7 so that it can be said that cross border trade construct in the inner model can be classified as strong. The value of $\mathrm{R}^{2}$ of cross border trade construct of 0.825 shows that cross border trade construct can be explained by social capital, institutional change and entrepreneurship construct at 82.5 percent, meanwhile the rest of 17.5 percent can be explained by other variables. The value of $\mathrm{R}^{2}$ of traders' welfare construct of 0.830 is greater than 0.7 so that it can be said that traders' welfare construct in the inner model can be classified as strong. The value shows that traders' welfare construct can be explained by cross border trade construct of 83 percent and the rest of 17 percent can be explained by other variables.

Stone Geiser $Q$ square test $\left(Q^{2}\right)$ can be calculated by: $Q^{2}=1-\left(1-R 1^{2}\right) \quad\left(1-R 2^{2}\right) \ldots\left(1-R^{2}\right)$, in which $\mathrm{R} 1^{2}, \mathrm{R} 2^{2}$ and $\mathrm{Rp}{ }^{2}$ are $\mathrm{R}$-square endogen variables in equation model. The value of $\mathrm{Q}^{2}$ has range between 0 $<\mathrm{Q}^{2}<1$, if the value of $\mathrm{Q}^{2}$ is closer to 1 , then the model is better (Abdillah and Hartono, 2015). Based on the value of $\mathrm{R}^{2}$ in Table 5.7, then the obtained value of $\mathrm{Q}^{2}$ for this research is:

$\mathrm{Q}^{2}=1-(1-0.872)(1-0.825)(1-0.830)$

$\mathrm{Q}^{2}=1-(0.128)(0.175)(0.17)$

$\mathrm{Q}^{2}=1-0.004$

$\mathrm{Q}^{2}=0.996$.

The result of $\mathrm{Q}^{2}$ calculation of 0.996 shows that the model has good predictive relevancy or high predictive prevalence, in which 99.6 percent of traders' welfare construct variation can be explained by cross border trade construct variation, whereas the rest of 0.4 percent can be explained by other construct outside of research model.

\subsection{The Testing of Direct Effect and Indirect Effect}

Direct effect in research model is shown by path coefficient value of all arrows with one end, whereas indirect effect can occur through the role of intervening variables. Total effect between variables can be seen through path coefficient value and total effect as the resultof PLS output. Direct effect between constructs in this research can be seen in path coefficient value showed in Figure 2.

Figure 2. Link Pathway Coefficient cross Latent Variables and Between LatentVariables and Its Indicators

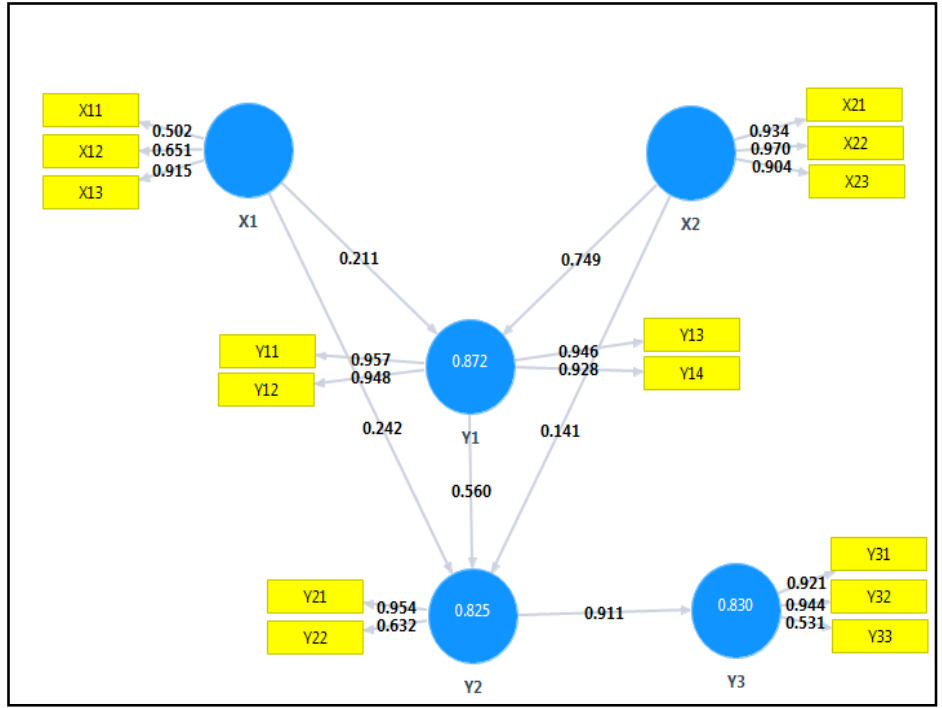

Source : Output data analysis by SEM-PLS

Based on link pathway coefficient value between variables in figure 2, it is seen that direct link of social capital (X1) towards entrepreneurship (Y1) by 0.211 and towards cross border trade (Y2) by 0.242 , direct link of institutional change (X2) towards entrepreneurship (Y1) by 0.141, whereas direct link of entrepreneurship (Y1) towards cross border trade (Y2) by 0.560 and direct link of cross border trade (Y2) towards welfare (Y3) is by 0.911 . Meanwhile indirect link is seen on relationship between social capital variable (X1) towards cross border trade (Y2) through entrepreneurship (Y1) by 0.560 and towards welfare (Y3) through cross border trade (Y2) by 0.911 . Indirect link of institutional change (X2) towards cross border trade through entrepreneurship (Y1) by 0.560 and towards welfare (Y3) by 0.911 , meanwhile indirect link of entrepreneurship towards welfare (Y3) through cross border trade (Y2) is by 0.911 . In brief, the value of direct link and indirect link cross variables can be seen in Table 5 . 
Table 5. Summary of Direct Effect and Indirect Effect Cross Variables

\begin{tabular}{|l|l|l|l|l|l|l|}
\hline \multirow{2}{*}{ Construct } & Entrepreneurship & \multicolumn{2}{l|}{ Cross border trade } & Welfare \\
\cline { 2 - 7 } & DR & IR & DR & IR & DR & IR \\
\hline Social Capital & 0.211 & - & 0.242 & 0.560 & - & 0.911 \\
\hline Institutional Changes & 0.749 & - & 0.141 & 0.560 & - & 0.911 \\
\hline Entrepreneurship & - & - & 0.560 & - & - & 0.911 \\
\hline Cross border trade & - & - & - & - & 0.911 & - \\
\hline
\end{tabular}

Information: DR; Direct Relationship, IR; Indirect Relationships

Source : Output data analysis by SEM-PLS

\subsection{Hypothesis Test}

Hypothesis test in this research was conducted with resampling bootstrap method by using T-test. Significance level of effect between variables was conducted by comparing t-test value with t-table value. Based on alpha $(\alpha)$ value of 0.05 and degree of freedom (df) the size of total amount of data-2, so t-table being used in this study was 1.65. The result of data processing with PLS for t-statistic in this study can be seen in Table 6 .

Table 6. Total effect and T-statistic

\begin{tabular}{|l|l|l|l|}
\hline & Original Sample $(\mathrm{O})$ & Standard Error (STERR) & T Statistics $(|\mathrm{O} / \mathrm{STERR}|)$ \\
\hline $\mathrm{X} 1$-> Y1 & 0,211 & 0,084 & 2,524 \\
\hline $\mathrm{X} 1$-> Y2 & 0,360 & 0,134 & 2,676 \\
\hline $\mathrm{X} 1$-> Y3 & 0,328 & 0,122 & 2,684 \\
\hline $\mathrm{X} 2$-> Y1 & 0,749 & 0,096 & 7,820 \\
\hline $\mathrm{X} 2$-> Y2 & 0,561 & 0,130 & 4,325 \\
\hline $\mathrm{X} 2$-> Y3 & 0,511 & 0,121 & 4,220 \\
\hline $\mathrm{Y} 1$-> Y2 & 0,560 & 0,156 & 3,581 \\
\hline $\mathrm{Y} 1$-> Y3 & 0,510 & 0,145 & 3,515 \\
\hline $\mathrm{Y} 2->\mathrm{Y} 3$ & 0,911 & 0,015 & 61,880 \\
\hline
\end{tabular}

Source : Output data analysis by SEM-PLS

1) The testing of Hypothesis 1 (H1): Social capital has positive and significant effect towards entrepreneurship of traders in border area.

Based on t-statistic value, the effect of social capital towards entrepreneurship shows positive value of 0.211 with t-statistic value of 2.524 is greater than t-table of $1.65(2.52>1.65)$ and significance level of 0.012 .

2) Testing of Hypothesis 2 (H2): Institutional change has positive and significant

effect towards entrepreneurship of traders in border area.

Based on t-statistic value as the result of data processing, the effect of institutional change towards entrepreneurship shows positive value of 0.749 with t-statistic value of $7.820>1.65$ (t-table) on the level of 0.05 and significance level of 0.000 .

3) Testing of Hypothesis 3 (H3): Social capital has positive and significant effect towards cross border trade. Based on t-statistic value, the effect of social capital towards cross border trade shows positive value of 0.242 with t-statistic value of $2.837>1.65$ (t-table) on the level of 0.05 and significance level of 0.007 .

4) Testing of Hypothesis 4 (H4): Institutional change has positive and insignificant effect towards cross border trade.

The result of data processing shows that the effect of institutional change towards cross border trade shows t-statistic value of $0.901>1.65$ ( $t$-table) on the level of 0.05 and significance level of 0.368 .

5) Testing of Hypothesis 5 (H5): Entrepreneurship has positive and significant effect towards cross border trade.

Based on t-statistic value as the result of data processing, the effect of entrepreneurship towards cross border trade shows positive value of 0.560 with t-statistic value of $3.581>1.65$ (t-table) on the level of 0.05 and significance level of 0.000 .

6) Testing of Hypothesis 6 (H6): Cross border trade has positive and significant effect towards welfare.

Based on t-statistic value, the effect of cross border trade towards traders' welfare shows t-statistic value of $61.880>1.65$ (t-table) on the level of 0.05 and significance level of 0.000 .

7) Testing of Hypothesis 7 (H7): Social capital has significant effect towards cross border trade through entrepreneurship.

The result of data processing shows that the effect of social capital towards cross border trade through entrepreneurship shows regression coefficient value of 0.118 .

8) Testing of Hypothesis 8 (H8): Institutional change has significant effect towards welfare through cross border trade.

Data shows that institutional change has an effect indirectly towards cross border trade by 0.420 . 
9) Testing of Hypothesis 9 (H9): Social capital has significant effect indirectly towards traders' welfare through cross border trade.

Data shows that social capital has an effect indirectly towards traders' welfare through cross border trade showing regression coefficient value of 0.220 .

10) Testing of Hypothesis 10 (H10): Institutional change has significant effect indirectly towards traders' welfare through cross border trade.

Based on the result of data processing, it shows that the effect of institutional change indirectly towards traders' welfare through cross border trade shows positive value with regression coefficient value of 0.128 .

11) Testing of Hypothesis 11 (H11): Entrepreneurship has significant effect indirectly towards traders' welfare through cross border trade.

Indirect effect of entrepreneurship towards traders' welfare through cross border trade shows positive value with regression coefficient value of 0.510 .

\section{Discussion}

Economic condition in border area of the Regency of North Central Timor in general is very weak that led the area to be set as underdeveloped region. Economic backwardness of local people has wide impact on economic life of local people and causing the shifting of social life's behavior. According to Yustika (2012), the main reason for institutional change was because of the interest of a party which needed it as an instrument to design economic activities in order to respond the public's needs. The society wished to get out from social phenomenon in the form of poverty, unemployed, dropout, bad nutrition and other social problems.

Post transition of Timor Leste as an independence nation, cross border area is unavoidable. The majority of traders are coming from population in the Regency of North Central Timor in the border area and the consumers are community in district of Oekusi. The factor of sociocultural similarity between communities leads to trading activity running smoothly. The closeness of relationship leads to government to seek for solution in the form of regulation to minimize illegal practice and facilitating the in and out flow of people and goods specific for border communities.

Cross border trade in the regency of North Central Timor has given positive contribution for local traders' income and also gives a lesson on the meaning of social value since it can help fellow brothers and sisters. Transaction process runs smoothly due to social capital factor of society as the character of society (physical quality). According to Limbong (2013), social capital shaped behavior value which bound the community in a working and community network which enabled for cooperation.

The changing of value of area location also changes people's behavior pattern. The transformation is marked with social engineering or institutional change, transformation of people's behavior in harnessing resources potential. According to Utari Vipriyanti (2011), social engineering is really needed to change the structure of economy, politics, law and culture. Part of community in border area now switches to become traders. Positive impact being obtained is that economic sufficiency for basic needs now fulfilled.

The government has great attention in supporting economic growth of traders in border area by giving special attention for availability of economic infrastructure, and preparing people's character to manage resources potential in order to improve the welfare of traders with various approaches.

\subsection{Conclusion}

\section{Conclusion And Suggestion}

Based on the result of discussion through data analysis by using SEM-PLS, then it can draw conclusion as follows:

1) Social capital which reflects character, has positive and significant effect towards entrepreneurship, cross border trade and traders' welfare in border area.

2) Institutional change is behavior transformation due to the shifting of surrounding environment, has positive effect towards entrepreneurship but does not have positive effect towards cross border trade due to kinship closeness factor.

3) Entrepreneurship has positive effect towards cross border trade and welfare.

4) Cross border trade has positive and significant effect towards cross border trade.

\subsection{Suggestion}

1) Social capital and institutional transformation of the traders is a strength.Therefore human resources in border area must be encouraged so that having competitive edge and ready to compete in globalization era.

2) Entrepreneurship approach is not only oriented to the pattern of sales and purchase but how the creation of community's small industries through the development of Small Micro Business (UMK), in particular community's creative industry. 
3) Approach and management of cross border trade is not only traditional in nature and only benefiting market players but to be more professional in order to become the source of income for region and state.

4) Traders' welfare is to be kept encouraged and not only limited to the fulfillment of basic needs (foods, clothes, and housing) but up to providing complete education and health facilities with low cost so that can be harnessed by public to improve the quality of human resources.

\section{Bibliography}

[1]. Abdillah,Willy dan Hartono, Jogiyanto.2015. Partial Least Square (PLS). AlternatifStructural Equations Modeling (SEM) dalamPenelitian Bisnis. Penerbit ANDI Yogyakarta.

[2]. Basri, Faisal. 2011. MenghadirkanSemangat Asean di Perbatasan. Kompas online, Mei 2011. Diakses tanggal 10/01/2016.

[3]. Bustami, Gumardi. 2012. Mendorong Perdagangan Lintas Batas. Warta Ekspor. Kementerian Perdagangan RI. Ditjen PEN/MJL.

[4]. Branch, M. C. 1998. Comprehensive Planning for the 21st Century: General, Theory \&Principles. Preager: London.Chandler, A. 1962. Strategy and Structure. Cambridge: MIT Press.Couldry, N .2004. In the Place of a Common Culture, What?Cultural Studies Vol. 26: 14

[5]. Case, Karl E. and Ray C. Fair. 1996. Principles of Economic, $4^{\text {th }}$ ed. News Jersey:Prentice-Hall International.

[6]. Chin, W. W., Marcolin, B. L., \& Newsted, P. N. (2003). A partial least squares approach for measuring interaction effects: Results from a Monte Carlo simulation study and an electronic mail emotion/adoption study. Information Systems Research

[7]. Deaton, Angus. 2003. Health, Inequality, and Economic Development. Journal of Economic Literature. Vol. XLI March 2003) pp. $113-158$

[8]. Hira, Anil dan Ron Hira. 2000. The Institutionalism; Contradictory Notions of Change, American Journal of Economics and Sociology. Vol. 59, No. 2, April: 267-282.

[9]. Inkong, Ala, DB Paranoan, Suarta Djaya. 2013. Peran Perdagangan Lintas Batas Dalam

[10]. Percepatan Pembangunan Infrastruktur Di Kecamatan Kayan Hulu Kabupaten Malinau. eJournal Adminstrative Reform, 2003, 1 (1): 54-65

[11]. Ireland, R. Duane, Michael A. Hitt and David G. Sirmon. 2003. AModel of StrategicEntrepreneurship, Journal of Management, 29;963.

[12]. Limbong, Bernard, 2013. Ekonomi Kerakyatan dan Nasionalisme Ekonomi. Penerbit Margaretha Pustaka, Percetakan PT. Dharma Karsa Utama, Jakarta

[13]. Manig, Winfriend. 1991.Rural Social and Economic Structures and Sosial Development. Stability and Change in Rural Institutions in Nort Pakistan. Socio-economic Studies on Rural Development. Vol. 85. Alano,Aachen.

[14]. Niebuhr, A and Stiller, S. 2001. Integration Effect in Border Regions - A Survey of Economic Theory and Empirical Studies. HWWA Discussion Paper.Hamburg

[15]. Rahardja, Pratama dan Mandala Manurung. 2002. Mikroekonomi dan makroekonomi. Lembaga Penerbit Fakultas Ekonomi Universitas Indonesia

[16]. Todaro, Mikhael. 2012. Development Economic. (Eleventh Edision). New York University

[17]. Undang undang Dasar Negara Republik Indonesia

[18]. Undang undang Republik Indonesia Nomor 43 Tahun 2008 tentang Wilayah Kawasan

[19]. Utari Vipriyanti, Nyoman. 2011. Modal Sosial dan Pembangunan Wilayah. Mengkaji Succes Story Pembangunan di Bali. Universitas Brawijaya Press (UB Press).

[20]. Yustika, Ahmad Erani. 2012. Ekonomi Kelembagaan. (paradigma, teori, dan kebijakan). Percetakan PT. Gelora Aksara Pratama 